\title{
PENERAPAN METODE PEMBELAJARAN MIND MAPPING DAN PROBLEM BASED LEARNING PADA MATA KULIAH AKUNTANSI KEUANGAN LANJUTAN
}

\author{
Oleh : Asepma Hygi Prihastuti, Suci Ramadhani \\ Sekolah Tinggi Ilmu Ekonomi Persada Bunda \\ Email: asepma@stiepersadabunda.ac.id
}

\begin{abstract}
Abstrak
Penelitian ini bertujuan untuk menganalisis pengaruh penggunaan metode Mind Mapping dan Problem Based Learning terhadap motivasi dan hasil belajar mahasiswa. Jenis penelitian ini adalah Penelitian Tindakan Kelas dengan subyek penelitian mahasiswa D3 Akuntansi STIE Persada Bunda yang menempuh mata kuliah Akuntansi Keuangan Lanjutan sebanyak 21 orang. Penelitian dilakukan 2 siklus dengan metode Mind Mapping menggunakan MindManager Pro 6 dan Problem Based Learning. Hasil penelitian menunjukan bahwa pada siklus 1, rata-rata nilai motivasi belajar mahasiswa sebesar 67,20\% meningkat menjadi 73,02\% dengan kategori tinggi pada siklus 2. Dan rata-rata nilai hasil belajar pada siklus 1 sebesar 70,00\% meningkat pada siklus 2 dengan rata-rata hasil belajar sebesar $85,71 \%$ dengan kategori sangat baik. Sehingga dapat disimpulkan bahwa dengan menggunakan metode pembelajaran Mind Mapping dan Problem Based Learning pada mata kuliah Akuntansi Keuangan Lanjutan semakin meningkatkan motivasi dan hasil belajar mahasiswa akuntansi di STIE Persada Bunda.
\end{abstract}

Kata Kunci: Mind Mapping, Problem Based Learning, Akuntansi Keuangan Lanjutan

\begin{abstract}
This study aims to analyze the effect of the use of Mind Mapping and Problem Based Learning methods on student motivation and learning outcomes. This type of research is Classroom Action Research with research subjects D3 Accounting STIE Persada Bunda students who take Advanced Accounting courses as many as 21 peoples. The study was conducted in 2 cycles with the Mind Mapping method using MindManager Pro 6 and Problem Based Learning. The results showed that in cycle 1, the average value of student learning motivation by $67.20 \%$ increased to $73.02 \%$ with a high category in cycle 2 . And the average value of learning outcomes in cycle 1 amounted to $70.00 \%$ increased in cycle 2 with an average learning outcome of $85.71 \%$ with a very good category. So it can be concluded that by using Mind Mapping learning methods and Problem Based Learning in the Advanced Accounting course further increases the motivation and learning outcomes of accounting students at STIE Persada Bunda.
\end{abstract}

Keyword: Mind Mapping, Problem Based Learning, Advanced Accounting 
PENDAHULUAN

Akuntansi keuangan lanjutan merupakan salah satu mata kuliah yang wajib diampu oleh mahasiswa D3 Akuntansi STIE Persada Bunda yang membahas konsep penggabungan usaha, laporan konsolidasi dan akuntansi mata uang asing. Laporan keuangan konsolidasi merupakan salah satu materi dalam mata kuliah akuntansi keuangan lanjutan. Materi ini sangat penting dalam pembelajaran akuntansi karena ketika lulusan masuk ke dunia kerja, diharapkan dapat membuat laporan keuangan bagi para penggunanya, khususnya laporan keuangan konsolidasi bagi perusahaan induk.

Mahasiswa Program D3 Akuntansi STIE Persada Bunda belum dapat secara optimal membuat laporan keuangan konsolidasi dalam perkuliahan, hal ini kemungkinan disebabkan kesulitan mahasiswa dalam memahami konsep keterkaitan antar sub bab materi laporan keuangan konsolidasi, sehingga menyebabkan rendahnya pemahaman mahasiswa terhadap materi tersebut, yang mengakibatkan rendahnya motivasi dan hasil belajar menjadi rendah. Hal ini mungkin disebabkan metode pembelajaran yang digunakan dosen yang masih didominasi metode pembelajaran konvensional, yaitu metode ceramah dan menggunakan media powerpoint. Proses pembelajaran dengan metode ini memiliki beberapa kekurangan, yaitu mahasiswa menjadi pasif, proses belajar membosankan, mahasiswa mengantuk, terdapat unsur paksaan untuk mendengarkan, akibatnya pembelajaran konvensional tidak mampu mengembangkan kemampuan mahasiswa secara optimal.

Berdasarkan dari permasalahan tersebut, dosen dituntut untuk mempunyai kreativitas tinggi dalam memilih metode pembelajaran yang sesuai dan menarik minat mahasiswa. Menurut Siregar (2014), Mind Mapping merupakan suatu teknik mencatat yang sangat efektif bagi pelajar dengan menangkap konsep pikiran dan gagasan menjadi lebih lengkap dan mudah. Syahidah (2015) menjelaskan bahwa penggunaan metode mind mapping dapat mendorong siswa berpikir sinergis, mempertajam ingatan dan melakukan imajinasi melalui asosiasi. Mind Mapping bertujuan untuk memberikan pandangan menyeluruh mengenai konsep suatu pokok bahasan dalam memahami keterkaitan hubungan dari konsep-konsep yang 
mempengaruhi pokok bahasan tersebut. Dengan metode pembelajaran Mind Mapping diharapkan mahasiswa dapat lebih memahami konsep keterkaitan antar sub bab materi laporan keuangan konsolidasi, sehingga meningkatkan pemahaman mahasiswa terhadap materi tersebut.

Untuk meningkatkan analisis dan penalaran mahasiswa terhadap permasalahan yang muncul dalam materi laporan keuangan konsolidasi, maka digunakan metode pembelajaran Problem Based Learning. Pujiati (2017) menyatakan bahwa model pembelajaran Problem Based Learning dapat meningkatkan kompetensi akuntansi. Metode Problem Based Learning menawarkan kebebasan kepada mahasiswa dalam proses pembelajaran, dimana mahasiswa diharapkan untuk terlibat dalam mengidentifikasi permasalahan, mengumpulkan data, dan menggunakan data tersebut untuk pemecahan masalah. Herliani (2017) menyatakan bahwa motivasi mahasiswa dalam belajar akuntansi mengalami peningkatan sebesar 29,43\% dengan menggunakan metode pembelajaran Problem Based Learning. Menurut Aisyaturrahmi peningkatan keaktifan dan hasil belajar mahasiswa yang dibuktikan dengan kenaikan nilai dan presentase ketuntasan belajar pada mata kuliah Akuntansi Keuangan Lanjutan.

Metode pembelajaran Mind Mapping dan Problem Based Learning ini dianggap sesuai untuk diterapkan dalam rangka meningkatkan motivasi dan hasil belajar mahasiswa serta menganalisis pengaruh penggunaan metode Mind Mapping dan Problem Based Learning terhadap motivasi dan hasil belajar mahasiswa pada mata kuliah Akuntansi Keuangan Lanjutan mahasiswa D3 Akuntansi STIE Persada Bunda.

\section{TINJAUAN PUSTAKA}

\section{Laporan Keuangan Konsolidasi}

Salah satu mata kuliah dalam proses pembelajaran akuntansi di perguruan tinggi adalah akuntansi keuangan lanjutan. Pada umumnya mata kuliah akuntansi keuangan lanjutan membahas tentang perusahaan induk dan anak, yang nantinya akan membuat laporan keuangan konsolidasi. Baker (2014) menyatakan Laporan keuangan konsolidasi merupakan laporan posisi keuangan dan hasil operasi induk 
perusahaan (entitas pengendali) dari satu/lebih anak perusahaan (entitas yang dikendalikan) seolah-olah entitas-entitas tersebut adalah satu entitas/perusahaan. Laporan keuangan konsolidasi ditujukan terutama untuk kepentingan pihak-pihak yang memiliki kepentingan jangka panjang dengan induk perusahaan, seperti pemegang saham dan kreditur.

\section{Mind Mapping}

Swadarma (2013), Mapping yaitu suatu teknik yang pemanfaatannya menggunakan keseluruhan otak dengan menggunakan citra visual dan prasarana grafis lainnya untuk membentuk suatu kesan. Olivia (2014) menyatakan bahwa penggunaan mapping ini menggunakan keterampilan kata, gambar, nomor, logika, ritme, warna dan ruang kesadaran dalam suatu cara yang unik, sehingga dapat memberikan kebebasan kepada peserta didik untuk menjelajahi otaknya secara tak terbatas. Dengan mind mapping informasi yang disampaikan akan lebih menarik secara visual, sehingga bisa membantu dalam mengelola informasi yang kita terima, dapat menambahkan keterkaitan dengan materi baru, serta menjadikan informasi lebih lama bertahan dalam ingatan.
Pada dasarnya proses belajar selalu melibatkan tiga aspek, yaitu visual, auditori, maupun kinestetik. Sehingga dengan mapping, ide, gagasan, permasalahan dan solusi yang terlintas dikepala dan membebani otak bawah sadar kita yang selama ini sulit untuk direkam, dapat dituangkan dalam mapping yang dituliskan diatas selembar kertas.

\section{Problem Based Learning}

Sanjaya (2010) menyatakan Problem Based Learning adalah rangkaian aktivitas pembelajaran yang penekanannya pada proses penyelesaian masalah yang dihadapi secara ilmiah. Ciri dari Problem Based Learning, yaitu: (1) Problem Based Learning merupakan rangkaian aktivitas pembelajaran, yang artinya dalam implementasi Problem Based Learning ada sejumlah kegiatan yang harus dilakukan pelajar, (2) Kegiatan pembelajaran diarahkan untuk menyelesaikan masalah, dan (3) Pemecahan masalah dilakukan menggunakan pendekatan pemikiran ilmiah.

Problem Based Learning dapat diterapkan: (a) Jika pengajar menginginkan agar pelajar dapat menguasai dan memahami materi secara 
penuh, (b) Jika pengajar bermaksud untuk mengembangkan keterampilan berpikir rasional pelajar, yaitu kemampuan menganalisis situasi, menerapkan pengetahuan yang mereka miliki dalam situasi baru, mengenal adanya perbedaan antara fakta dan pendapat, serta mengembangkan kemampuan dalam membuat judgment secara objektif, (c) Jika pengajar ingin kemampuan pelajar untuk memecahkan masalah serta membuat tantangan intelektual bagi pelajar, (d) Jika pengajar ingin agar pelajar memahami hubungan antara apa yang dipelajari dengan kenyataan dalam kehidupan (hubungan antara teori dengan kenyataan).

Amir (2013) menjelaskan tujuh langkah proses Problem Based Learning yaitu sebagai berikut: (1) Mengklarifikasi istilah dan konsep yang belum jelas, (2) Merumuskan masalah, (3) Menganalisis masalah, (4) Menata gagasan secara sistematis dan menganalisisnya, (5) Memformulasikan tujuan pembelajaran, (6) Mencari informasi tambahan dari sumber yang lain, dan (7) Menggabungkan dan menguji infromasi baru, dan membuat laporan.

\section{Penelitian yang Relevan}

Peneliti mengutip beberapa penelitian untuk mendukung teori-teori yang digunakan dalam penelitian ini, yaitu:

1. Pujiati (2017) membahas tentang implementasi model Problem Based Learning dalam meningkatkan kompetensi akuntansi. Hasil penelitian menunjukkan bahwa model Problem Based Learning pada mata kuliah Akuntansi Keuangan Menengah I dapat meningkatkan kompetensi akuntansi.

2. Thomas (2016) membahas tentang pengembangan perangkat pembelajaran dan modul metodologi penelitian berbasis Problem Based Learning bagi mahasiswa pendidikan akuntansi. Hasil penelitian menunjukkan adanya pengembangan dua produk, yaitu Satuan Acara Perkuliahan (SAP) dan modul metodologi penelitian pendidikan akuntansi yang menerapkan metode pembelajaran berbasis masalah.

3. Herliani (2017) membahas tentang model pembelajaran Problem Based Learning (PBL) berbasis blended learning untuk meningkatkan motivasi dan hasil belajar siswa. 
Hasil penelitian menunjukan bahwa motivasi mahasiswa dalam belajar akuntansi mengalami peningkatan sebesar $29,43 \%$.

4. Aisyaturrahmi (2016) membahas tentang peningkatan keaktifan dan hasil belajar mahasiswa pada mata kuliah Akuntansi Keuangan Lanjutan dengan materi kantor pusat dan kantor cabang yang memadukan model Cases Based Learning dan Direct Instruction. Hasil penelitian ini menunjukkan peningkatan keaktifan dan hasil belajar mahasiswa yang dibuktikan dengan kenaikan nilai dan presentase ketuntasan belajar pada mata kuliah Akuntansi Keuangan Lanjutan.

5. Syahidah (2015) membahas tentang bagaimana metode pembelajaran mind mapping sebagai upaya dalam mengembangkan kreativitas siswa dalam pembelajaran ekonomi. Hasil penelitiannya menjelaskan bahwa penggunaan metode mind mapping dapat mendorong siswa berpikir sinergis, mempertajam ingatan dan melakukan imajinasi melalui asosiasi.
6. Siregar (2014) membahas tentang penggunaan metode Mind Mapping terhadap prestasi belajar siswa. Peta pikiran di terapkan dan digunakan untuk memberi pandangan secara keseluruhan pada suatu pokok permasalan dan membantu dalam mengingat, mendapatkan ide, yang pasti memunculkan kreatif dan inovatif siswa.

7. Mutmainah (2008) membahas tentang penerapan metode pembelajaran kooperatif berbasis kasus yang berpusat pada mahasiswa terhadap efektivitas pembelajaran akuntansi keperilakuan. Hasil penelitiannya menunjukkan bahwa hasil pemebelajaran dengan metode pembelajaran kooperatif berbasis kasus lebih baik dibandingkan hasil pembelajaran dengan metode tradisional, baik bagi dosen maupun mahasiswa.

\section{METODE PENELITIAN}

Penelitian ini merupakan Penelitian Tindakan Kelas (PTK) yang dimaksudkan untuk memberi informasi bagaimana tindakan yang tepat untuk meningkatkan motivasi belajar dan hasil belajar 
mahasiswa, khususnya mata kuliah Akuntansi Keuangan Lanjutan materi Konsolidasi pada Anak Perusahaan yang Dimiliki Penuh dan Konsolidasi pada Anak Perusahaan yang Dimiliki Kurang dari Kepemilikan Penuh dengan metode pembelajaran Mind Mapping dan Problem Based Learning (PBL). Jumlah mahasiswa yang akan diteliti 21 orang. Penelitian ini dilakukan sebanyak 2 (dua) siklus, dimana masing-masing siklus meliputi 4 tahap kegiatan, yaitu: (1) tahap perencanaan (plan), (b) tahap pelaksanaan (action), (3) tahap pengamatan (observation), dan (4) tahap refleksi (reflection).

Adapun rincian kegiatan masingmasing tahap pelaksanaan PTK pada siklus pertama adalah sebagai berikut:

1. Tahap perencanaan (plan). Pada tahap ini peneliti melakukan kegiatan dalam mempersiapkan kelengkapan perangkat pembelajaran, seperti: penyusunan Rencana Pembelajaran Semester (RPS), buku, aplikasi Mind Mapping dan Problem Based Learning yang berhubungan dengan metode pembelajaran, dan observer.

2. Tahap Pelaksanaan (action). Pada tahap ini, peneliti melakukan kegiatan yang terbagi dalam 3 bagian, yaitu sebagai berikut.

Kegiatan Pendahuluan; pada bagian ini peneliti melakukan kegiatan persiapan pisik dan psikis, apersepsi, serta memberikan motivasi

Kegiatan Inti; pada bagian ini meliputi: (1) Dosen menyampaikan kompetensi yang ingin dicapai; (2) Dosen membagi mahasiswa dalam beberapa kelompok, setiap kelompok terdiri atas 5-6 orang mahasiswa; (3) Menginstruksikan mahasiswa untuk menginstal aplikasi MindManager Pro 6 di laptop masing-masing, kemudian mensimulasikan tentang bagaimana cara penggunaannya; (4) Dosen menyajikan materi tentang Konsolidasi pada Anak Perusahaan yang Dimiliki Penuh dengan membuat peta pikirannya (Mind Mapping) menggunakan aplikasi MindManager Pro 6 sebagai aplikasi pembantu membuat Mind Mapping; (5) Dosen memberikan soal kasus sebagai implementasi metode pembelajaran Problem Based Learning (PBL); (6) Mahasiswa berdiskusi dengan kelompoknya masing-masing, kemudian membuat Problem Mapping 
sebagai Problem Solving dari soal kasus yang diberikan dengan membuat Mind Mapping menggunakan aplikasi MindManager Pro 6; (7) Setelah selesai, perwakilan kelompok diminta untuk mempresentasikan hasil diskusi jawaban dari soal kasus yang diberikan; dan (8) Dosen memberikan klarifikasi jawaban yang benar.

Kegiatan penutup; pada bagian ini peneliti melakukan kegiatan: menyimpulkan inti dari materi yang dibahas, permasalahan dan solusi soal kasus yang diberikan.

3. Tahap pengamatan (observation); Pada tahap ini, Observer melakukan observasi terhadap aktivitas dosen menggunakan lembar observasi yang telah disiapkan. Bagi mahasiswa untuk menilai tingkat motivasi belajarnya setelah pembelajaran akan disebarkan kuisioner. Sedangkan untuk hasil belajar akan dihitung nilainya dari posttest yang dilakukan.

4. Tahap refleksi (reflection); Pada tahap ini dilakukan pertemuan antara observer dengan peneliti selesai mengajar untuk mengevaluasi, menganalisis, dan mendiskusikan hasil observasi guna menetapkan rencana perbaikan di siklus berikutnya.

Sedangkan perencanaan kegiatan pada siklus 2 akan disusun kemudian berdasarkan hasil refleksi siklus sebelumnya. Data yang diperlukan pada penelitian ini adalah: (1) aktivitas dosen menerapkan metode pembelajaran Mind Mapping dan Problem Based Learning (PBL), dan (2) aktivitas mahasiswa selama mengikuti kuliah Akuntansi Keuangan Lanjutan dengan materi Konsolidasi pada Anak Perusahaan yang Dimiliki Kurang dari Kepemilikan Penuh dengan membuat peta pikirannya (Mind Mapping) menggunakan aplikasi MindManager Pro 6 dan Dosen memberikan soal kasus sebagai implementasi metode pembelajaran Problem Based Learning (PBL). Data aktivitas dosen dikumpulkan menggunakan lembar observasi dengan pengukuran masing-masing 0-5 untuk aktivitas dosen (tidak dilakukan, sangat kurang baik, kurang baik, baik, dan sangat baik), dan kuisioner untuk penilaian motivasi mahasiswa.

Untuk menjawab rumusan masalah, data dianalisis menggunakan analisis distribusi frekuensi berupa tabel dan grafik garis, seperti berikut: 
(a) Analisis distribusi frekuensi menggunakan table; dengan formula

$$
\begin{gathered}
\mathrm{P}=\underset{\mathrm{N}}{\mathrm{F}} \times 100 \% \\
\end{gathered}
$$

(b) Hasilnya akan dikonsultasikan dengan kriteria kategori pengukuran aktivitas dosen dan motivasi mahasiswa seperti berikut:
Tabel 1 Kategori Pengukuran Aktivitas Dosen

\begin{tabular}{|c|c|}
\hline $\begin{array}{c}\text { Kriteria } \\
\text { Pengukuran }\end{array}$ & Aktivitas Dosen \\
\hline$>80 \%-100 \%$ & Sangat Baik \\
\hline$>60 \%-80 \%$ & Baik \\
\hline$>40 \%-60 \%$ & Cukup \\
\hline$>20 \%-40 \%$ & Kurang \\
\hline $0 \%-20 \%$ & Sangat Kurang \\
\hline
\end{tabular}

Sumber: Gimin, dkk (2008: 9)

Dalam menilai motivasi mahasiswa, peneliti menggunakan kuisioner dengan 9 item pertanyaan yang disebarkan kepada mahasiswa setelah selesai perkuliahan. Dari hasil kuesioner motivasi belajar. Capaian motivasi akan diukur menggunakan ukuran kategori seperti pada table berikut:

Tabel 2 Tabel Penilaian Motivasi Belajar Mahasiswa

\begin{tabular}{|c|c|}
\hline Range score & Kategori \\
\hline$>75-100$ & Sangat Tinggi \\
\hline$>50-75$ & Tinggi \\
\hline$>25-50$ & Rendah \\
\hline$<25$ & Sangat rendah \\
\hline
\end{tabular}

Sedangkan untuk menilai hasil belajar mahasiswa, peneliti menganalisis hasil tes mahasiswa dengan menghitung jumlah jawaban benar dan menghitung nilai akhir setiap mahasiswa sehingga akan terlihat nilai peningkatan diatas 65 yang merupakan nilai minimal. Nilai tersebut merupakan nilai minimal pada perkuliahan Akuntansi Keuangan Lanjutan 
Tabel 3 Tabel Penilaian Hasil Belajar Mahasiswa

\begin{tabular}{|c|c|c|}
\hline Range score & Kategori & Nilai \\
\hline $80-100$ & Sangat Baik & A \\
\hline $65-79$ & Baik & B \\
\hline $55-64$ & Cukup & C \\
\hline$<55$ & Kurang & D \\
\hline
\end{tabular}

Sumber: Tabel Penilaian STIE Persada Bunda

HASIL DAN PEMBAHASAN

Secara deskriptif penelitian ini menemukan skor aktivitas dosen yang mengajar menggunakan metode pembelajaran Mind Mapping dan Problem Based Learning (PBL) pada mahasiswa STIE Persada Bunda Tahun Ajaran 2018/2019 adalah sebagai berikut

\begin{tabular}{|c|c|c|c|}
\hline \multirow{2}{*}{ No } & \multirow{2}{*}{ Aktivitas Dosen } & \multicolumn{2}{|c|}{ Siklus } \\
\hline & & 1 & 2 \\
\hline 1 & Dosen menyampaikan kompetensi yang ingin dicapai & 4 & 5 \\
\hline 2 & $\begin{array}{l}\text { Dosen membagi mahasiswa dalam beberapa kelompok, } \\
\text { setiap kelompok terdiri atas 5-6 orang mahasiswa. }\end{array}$ & 3 & 4 \\
\hline 3 & $\begin{array}{l}\text { Menginstruksikan mahasiswa untuk menginstal aplikasi } \\
\text { MindManager Pro } 6 \text { di laptopnya, kemudian } \\
\text { mensimulasikan cara penggunaannya. }\end{array}$ & 3 & 3 \\
\hline 4 & $\begin{array}{l}\text { Dosen menyajikan materi tentang Konsolidasi pada Anak } \\
\text { Perusahaan yang Dimiliki Penuh (Siklus 1) dan } \\
\text { Konsolidasi pada Anak Perusahaan yang Dimiliki Kurang } \\
\text { dari Kepemilikan Penuh (Siklus 2) dengan membuat peta } \\
\text { pikirannya (Mind Mapping) menggunakan aplikasi } \\
\text { MindManager Pro } 6 \text { sebagai aplikasi pembantu membuat } \\
\text { Mind Mapping. }\end{array}$ & 2 & 4 \\
\hline 5 & $\begin{array}{l}\text { Dosen memberikan soal kasus sebagai implementasi } \\
\text { metode pembelajaran Problem Based Learning (PBL). }\end{array}$ & 3 & 4 \\
\hline 6 & $\begin{array}{l}\text { Mahasiswa berdiskusi dengan kelompoknya masing- } \\
\text { masing, kemudian membuat Problem Mapping sebagai } \\
\text { Problem Solving dari soal kasus yang diberikan dengan } \\
\text { membuat Mind Mapping menggunakan aplikasi } \\
\text { MindManager Pro 6. }\end{array}$ & 3 & 4 \\
\hline 7 & $\begin{array}{l}\text { Setelah selesai, perwakilan kelompok diminta untuk } \\
\text { mempresentasikan hasil diskusi jawaban dari soal kasus } \\
\text { yang diberikan. }\end{array}$ & 4 & 4 \\
\hline 8 & Dosen memberikan klarifikasi jawaban yang benar. & 3 & 4 \\
\hline \multicolumn{2}{|r|}{ Jumlah Skor } & 25 & 32 \\
\hline \multicolumn{2}{|c|}{ Persentase $(\%)$} & $62,5 \%$ & $80,0 \%$ \\
\hline
\end{tabular}

Tabel IV.1 Aktivitas dosen yang mengajar menggunakan metode pembelajaran Mind 4 Mapping dan Problem Based Learning (PBL) pada mahasiswa STIE Persada Bunda Tahun Ajaran 2018/2019 
Dari tabel 4 dapat dijelaskan skor aktivitas peneliti mulai dari siklus 1 hingga 2 selalu mengalami peningkatan dimana pada siklus 1 mendapat nilai $62,5 \%$ (kategori Baik) dan pada siklus 2 mendapat nilai $80,0 \%$ (kategori baik). Hal ini disebabkan peneliti selalu menggunakan kekurangan yang dialami sebagai pembelajaran untuk siklus berikutnya. Pada siklus 1, peneliti memperoleh skor kurang pada 1 aspek, yaitu kegiatan ke 4 dengan skor 2. Hasil refleksi, observer menyatakan "pada kegiatan ke 4 peneliti menyajikan materi terlalu cepat, sehingga mahasiswa banyak yang kurang paham, apalagi penggunaan aplikasi MindManager Pro 6 yang dianggap masih baru". Untuk mengatasi kekurangan ini, maka pada siklus berikutnya, dalam mengajar peneliti menjelaskan mengenai materi dengan perlahan dan adanya penekanan pada hal yang dianggap penting, serta mahasiswa disuruh langsung mengaplikasikan pada laptopnya. Pada siklus 2 secara kumulatif peneliti sudah dapat mengimplementasikan metode pembelajaran Mind Mapping dan Problem Based Learning dengan nilai $80,0 \%$ (kategori baik), namun belum maksimal. Observer menyatakan "beberapa aspek yang masih memerlukan perhatian, adalah kegiatan 3 dan 7 yang dianggap tidak ada peningkatan, seharusnya ketika dosen mensimulasikan penggunaan aplikasi MindManager Pro 6 sambil berkeliling meninjau yang dikerjakan mahasiswa sudah benar atau salah ataukah mahasiswa mengalami kesulitan dalam pemanfaatan aplikasi tersebut dan untuk kegiatan 7 mahasiswa yang maju sebagai perwakilan selalu mahasiswa yang aktif, sehingga tidak dapat diketahui secara maksimal apakah mahasiswa yang lain yang tidak menjadi perwakilan paham atau tidak terhadap materi yang dibahas".

Hasil motivasi belajar mahasiswa pada siklus 1 dan siklus 2 seperti pada tabel berikut: 
Tabel 5 Motivasi Belajar Mahasiswa

\begin{tabular}{|c|c|c|c|}
\hline \multirow{2}{*}{ No } & \multirow{2}{*}{ Indikator Motivasi Belajar } & \multicolumn{2}{|c|}{ Motivasi (dalam \%) } \\
\hline & & Siklus 1 & Siklus 2 \\
\hline 1 & $\begin{array}{l}\text { Saya memperhatikan dengan serius saat dosen } \\
\text { menjelaskan materi Konsolidasi pada Anak } \\
\text { Perusahaan yang Dimiliki Penuh }\end{array}$ & 77.27 & 87.50 \\
\hline 2 & $\begin{array}{l}\text { Saya mengusahakan sampai bisa pada saat } \\
\text { mengalami kesulitan dalam belajar materi } \\
\text { Konsolidasi pada Anak Perusahaan yang Dimiliki } \\
\text { Penuh }\end{array}$ & 80.68 & 86.36 \\
\hline 3 & $\begin{array}{l}\text { Saya berusaha mencari berbagai bentuk soal latihan } \\
\text { dalam belajar materi Konsolidasi pada Anak } \\
\text { Perusahaan yang Dimiliki Penuh }\end{array}$ & 59.09 & 64.77 \\
\hline 4 & $\begin{array}{l}\text { Untuk mendalami materi Konsolidasi pada Anak } \\
\text { Perusahaan yang Dimiliki Penuh saya lebih suka } \\
\text { bekerja mandiri daripada bersama-sama orang } \\
\text { banyak dengan kawan-kawan sekelas saya }\end{array}$ & 68.18 & 72.73 \\
\hline 5 & $\begin{array}{l}\text { Dalam mengerjakan tugas-tugas materi Konsolidasi } \\
\text { pada Anak Perusahaan yang Dimiliki Penuh, saya } \\
\text { lebih suka jika bentuk atau model tugasnya } \\
\text { berbeda-beda (bervariasi) }\end{array}$ & 69.32 & 75.00 \\
\hline 6 & $\begin{array}{l}\text { Dalam melakukan diskusi materi Konsolidasi pada } \\
\text { Anak Perusahaan yang Dimiliki Penuh, saya dapat } \\
\text { mempertahankan pendapat saya }\end{array}$ & 70.45 & 73.86 \\
\hline 7 & $\begin{array}{l}\text { Dalam melakukan diskusi, saya tidak cepat } \\
\text { menerima pendapat/tanggapan yang diberikan } \\
\text { kawan-kawan saya. }\end{array}$ & 70.45 & 76.14 \\
\hline $8 \mathrm{a}$ & $\begin{array}{l}\text { Saya senang mencari soal-soal latihan materi } \\
\text { Konsolidasi pada Anak Perusahaan yang Dimiliki } \\
\text { Penuh }\end{array}$ & 53.57 & 57.14 \\
\hline $8 b$ & $\begin{array}{l}\text { Saya senang mengerjakan soal-soal latihan materi } \\
\text { Konsolidasi pada Anak Perusahaan yang Dimiliki } \\
\text { Penuh }\end{array}$ & 65.48 & 71.43 \\
\hline & Motivasi Belajar Mahasiswa & 67.20 & 73.02 \\
\hline
\end{tabular}

Dari table di atas menunjukan mahasiswa yang diberikan perkuliahan menggunakan metode pembelajaran Mind
Mapping dan Problem Based Learning memiliki motivasi belajar sebesar $67,20 \%$ (pada siklus 1) dan meningkat motivasi 
belajarnya menjadi $73,02 \%$ pada siklus ke 2 , Hasil belajar mahasiswa pada siklus 1 atau secara rata-rata motivasinya sebesar dan siklus 2 seperti pada tabel berikut: $70,11 \%$.

Tabel 6 Distribusi Frekuensi Hasil Belajar Mahasiswa

\begin{tabular}{|c|c|c|c|c|}
\hline & & & \multicolumn{2}{|c|}{ Frekuensi Hasil Belajar } \\
\cline { 3 - 5 } No. & Range score & Kategori & Siklus 1 & Siklus 2 \\
\hline 1 & $80-100$ & Sangat Baik & 7 & 17 \\
\hline 2 & $65-79$ & Baik & 9 & 2 \\
\hline 3 & $55-64$ & Cukup & 2 & 1 \\
\hline 4 & $<55$ & Kurang & 3 & 1 \\
\hline & \multicolumn{2}{|c|}{ Rata-rata } & 70,00 & 85,71 \\
\hline
\end{tabular}

Sumber: Data diolah

Dari table di atas dapat dijelaskan bahwa pada siklus 1 mayoritas mahasiswa memperoleh nilai dalam kategori baik (6579) sebanyak 9 orang (43\%) dengan ratarata nilai 70,00, Sedangkan pada siklus ke 2 mengalami peningkatan, mayoritas mahasiswa memperoleh nilai dalam kategori sangat baik (80-100) sebanyak 17 orang $(81 \%)$ dengan rata-rata nilai 85,71 .
Aktivitas dosen seperti pada table 4 di atas berpengaruh pada motivasi mahasiswa dalam proses pembelajaran Akuntansi Keuangan Lanjutan dengan materi Konsolidasi pada Anak Perusahaan yang Dimiliki Penuh dan Konsolidasi pada Anak Perusahaan yang Dimiliki Kurang dari Kepemilikan Penuh, sebagaimana tabel dibawah ini:

Tabel 7 Rata-rata persentase skor Aktivitas Dosen, Motivasi Mahasiswa dan Hasil Belajar Mahasiswa

\begin{tabular}{|c|c|c|c|}
\hline Keterangan & Aktivitas Dosen & $\begin{array}{c}\text { Motivasi Belajar } \\
\text { Mahasiswa }\end{array}$ & $\begin{array}{c}\text { Hasil Belajar } \\
\text { Mahasiswa }\end{array}$ \\
\hline Siklus 1 & $62,50 \%$ & $67.20 \%$ & $70,00 \%$ \\
\hline Siklus 2 & $80,00 \%$ & $73.02 \%$ & $85,71 \%$ \\
\hline
\end{tabular}

Sumber: Data diolah

Berdasarkan tabel 7 diatas menunjukan bahwa pada Siklus 1 dengan metode pembelajaran Mind Mapping dan Problem Based Learning, rata-rata nilai 
motivasi belajar mahasiswa mengalami peningkatan dengan nilai $67,20 \%$ yang dikategorikan Tinggi, dan rata-rata nilai hasil belajar meningkat menjadi $70,00 \%$ dengan kategori baik. Sedangkan pada Siklus 2, diperoleh rata-rata nilai motivasi mahasiswa sebesar 73,02\% dengan kategori tinggi, untuk rata-rata hasil belajar sebesar $85,71 \%$ dengan kategori sangat baik yang mengalami peningkatan yang signifikan dari siklus 1. Sehingga dapat disimpulkan bahwa dengan menggunakan metode pembelajaran Mind Mapping dan Problem
Based Learning yang semakin sempurna (baik) pada mata kuliah Akuntansi Keuangan Lanjutan dengan materi Konsolidasi pada Anak Perusahaan yang Dimiliki Penuh dan Konsolidasi pada Anak Perusahaan yang Dimiliki Kurang dari Kepemilikan Penuh semakin meningkatkan motivasi dan hasil belajar mahasiswa akuntansi di STIE Persada Bunda. Perkembangan aktivits dosen, motivasi belajar, dan hasil belajar mahasiswa dari siklus 1 ke siklus 2 secara singkat dapat dilihat dengan grafik berikut.

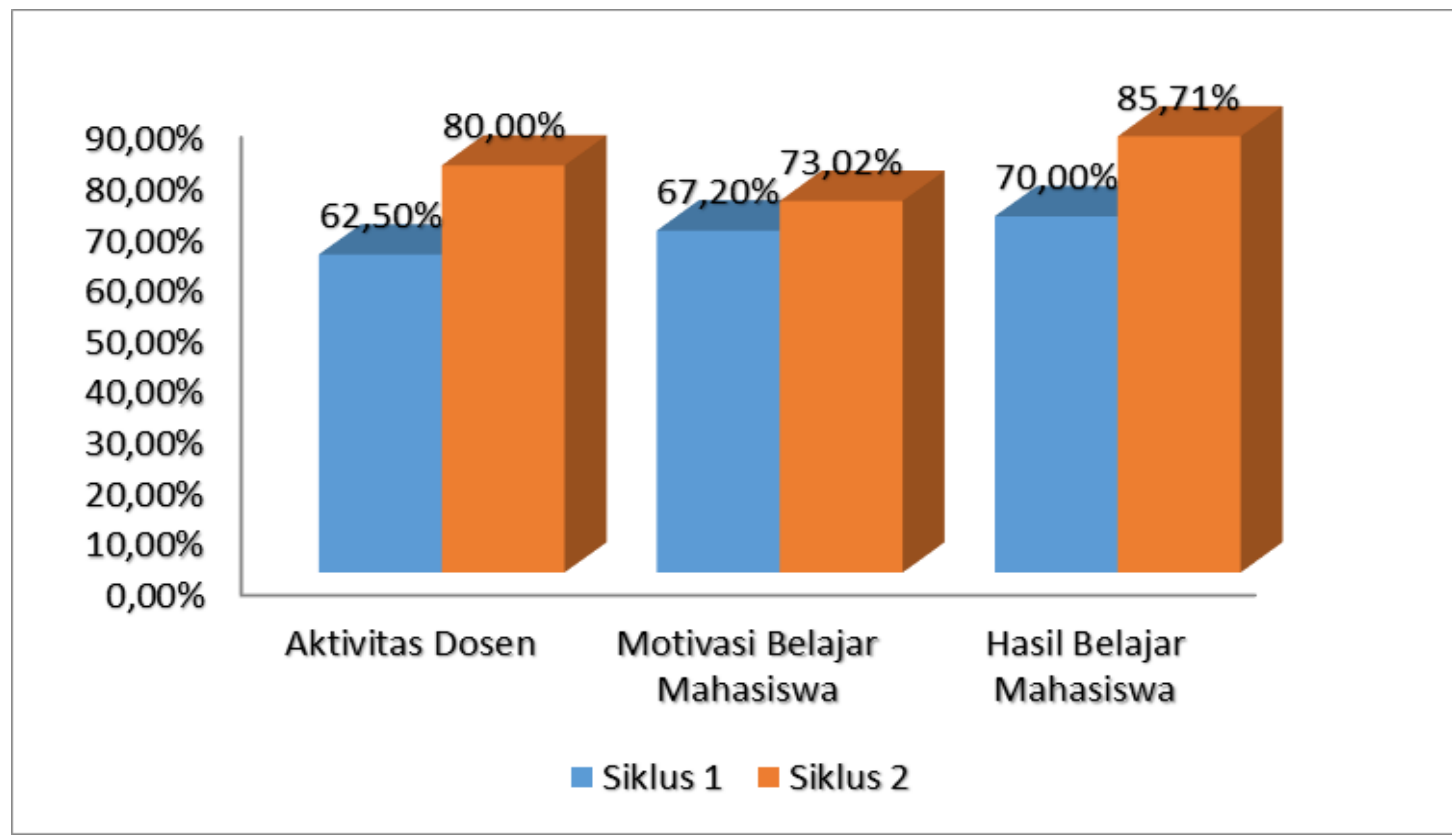

Gambar 1 Perkembangan Aktivitas dosen, Motivasi belajar, dan Hasil belajar mahasiswa dari siklus 1 ke siklus 2 . 
Hasil penelitian ini sejalan dengan hasil penelitian Farah (2019) bahwa penerapan Problem Based Learning berbantu Mind Mapping pada materi pokok $\mathrm{PPh}$ Final dan Tidak Final dapat meningkatkan hasil belajar siswa. Zubaidah (2016), Syahidah (2015) dan Siregar (2014) membahas tentang bagaimana metode pembelajaran mind mapping sebagai upaya dalam mengembangkan kreativitas siswa dalam pembelajaran ekonomi dan meningkatkan prestasi belajar siswa serta berpengaruh terhadap hasil belajar. Hasil penelitian Herliani dan Choms (2017), Aisyaturrahmi (2016) dan Luthfi (2015) menyatakan bahwa model pembelajaran Problem Based Learning (PBL) meningkatkan motivasi, keaktifan dan hasil belajar mahasiswa.

\section{SIMPULAN DAN SARAN}

\section{SIMPULAN}

1. Skor aktivitas dosen mengalami peningkatan dari siklus 1 ke 2 dengan metode pembelajaran Mind Mapping dan Problem Based Learning .

2. Motivasi belajar mahasiswa mengalami peningkatan dari siklus 1 ke 2 dengan metode pembelajaran Mind Mapping dan Problem Based Learning.

3. Hasil belajar mahasiswa meningkat dari siklus 1 ke 2 dengan metode pembelajaran Mind Mapping dan Problem Based Learning.

4. Dengan menggunakan metode pembelajaran Mind Mapping dan Problem Based Learning yang semakin sempurna (baik) pada mata kuliah Akuntansi Keuangan Lanjutan semakin meningkatkan motivasi dan hasil belajar mahasiswa akuntansi di STIE Persada Bunda.

\section{SARAN}

1. Untuk penelitian selanjutnya dapat digunakan metode pembelajaran lainnya untuk mempermudah pemahaman mahasiswa pada mata kuliah Akuntansi Keuangan Lanjutan.

2. Media pembelajaran dapat dikembangkan dengan menggunakan ePBL.

\section{DAFTAR PUSTAKA}

Adilah, Nida. (2017). Perbedaan Hasil Belajar IPA melalui Penerapan Metode Mind Map dengan Metode Ceramah. Indonesian Journal of 
Primary Education, Vol 1 No 1 (2017) 98-103

Aisyaturrahmi. (2016). Cases Based Learning Dan Direct Instruction Untuk Meningkatkan Keaktifan Serta Hasil Belajar Studi Pada Mahasiswa Mata Kuliah Akuntansi Keuangan Lanjutan. Jurnal AN-NISBAH, Vol. 02, No. 02, April 2016.

Amir, Taufiq, M. (2013). Inovasi Pendidikan Melalui Problem Based Learning. Kencana Prenada Media Group: Jakarta

Ayu, Dyah DS. (2012). Perbedaan Pengaruh Penggunaan Metode Mind Map Dan Metode Ceramah Terhadap Hasil Belajar IPS Siswa Kelas IV SD Negeri Keputran A Yogyakarta Tahun Ajaran 2011/2012. Skripsi. Universitas Negeri Yogyakarta

Baker, E. Richard, etc. (2014). Akuntansi Keuangan Lanjutan (Perspektif Indonesia) Buku 1. Jakarta: Salemba Empat. Sss

Farah, Rr. Aisa, Aini dan Lusita. (2019) Penerapan Model Problem Based Learning Berbantu Mind Mapping Untuk Meningkatkan Hasil Belajar Materi Pokok PPh Final Dan Tidak Final Di Kelas XII Akuntansi 8 SMKN 1 Surabaya. Jurnal Pendidikan Akuntansi: Volume 07 Nomor 01 Tahun 2019, 1 -6

Gimin. (2008) Instrument dan Pelaporan Hasil dalam Penelitian Tindakan Kelas. Pekanbaru
Herliani, Rini dan Choms Gary G T Sibarani. (2017). Penerapan Model Pembelajaran Problem Based Learning (PBL) Berbasis Blended Learning Untuk Meningkatkan Motivasi Dan Hasil Belajar Akuntansi. Jurnal Teknologi Pendidikan, Vol. 10 No. 2 Oktober 2017, p-ISSN; 1979-6692, e-ISSN: 2407-7437

Luthfi, Sigit Santosa, dan Sri Sumaryati. (2015) Upaya Peningkatan Motivasi Belajar Komputer Akuntansi Melalui Penerapan Model Problem Based Learning Pada Siswa Kelas XI KU 2 SMK Negeri 1 Sukoharjo Tahun Pelajaran 2014/2015. Jurnal Tata Arta UNS, Vol. 1, No. 1, hlm. 103113. Juli, 2015

Mutmainah, Siti. (2008). Pengaruh Penerapan Metode Pembelajaran Kooperatif Berbasis Kasus Yang Berpusat Pada Mahasiswa Terhadap Efektivitas Pembelajaran Akuntansi Keperilakuan. Simposium Nasional Akuntansi 11 (SNA 11), 23 - 24 Juli 2008, Universitas Tanjung Pura Pontianak.

Olivia, Femi. (2014). 5-7 Menit Asyik Mind Mapping Pelajaran Sekolah. Jakarta: Gramedia.

Pujiati, Darwin Bangun dan Rahmah Dianti Putri. (2017). Model Problem Based Learning dalam meningkatkan Kompetensi Akuntansi. Economic Education and Enterpreneurship Journal, Terbitan 1, Jilid 1, hal. 1-9. 
Rahayuningsih, Murti. (2016). Peningkatan Motivasi Dan Hasil Belajar Akuntansi Jasa Dengan Pembelajaran Problem Based Learning. Indonesian Journal of Education and Learning, hal. 43-51.

Sanjaya, W. (2010). Strategi Pembelajaran Berorientasi Standar Proses Pendidikan. Jakarta: Kencana.

Siregar, Rosliana. (2014). Penggunaan Metode Mind Mapping terhadap Prestasi Belajar Siswa. Jurnal Pengabdian Kepada Masyarakat, Vol. 20, Nomor 75, Tahun XX, Maret 2014, Hal. 84-88.

Swadarma, Doni. (2013). Penerapan Mind Mapping dalam Kurikulum Pembelajaran. Jakarta: PT. Elex Media Komputindo.

Syahidah, Nuris. (2015). Metode Pembelajaran Mind Mapping Sebagai Upaya Mengembangkan Kreativitas Siswa Dalam Pembelajaran Ekonomi. Prosiding Seminar Nasional 9 Mei 2015.

Thomas, Partono dan Ahmad Nurkhin. (2016). The Development Of Learning Sets And Research Methodology Module Using Problem Based Learning For Accounting Education Students. Journal of Accounting and Bussiness Education, September 2016.

Zubaidah, Inas, Sahar. (2015) Pengaruh Metode Pembelajaran Mind Map Terhadap Hasil Belajar IPA Siswa Kelas VII SMP Negeri 1 Polanharjo
Klaten Semester Genap Tahun Ajaran 2015/2016. Skripsi. Fakultas Keguruan dan Ilmu Pendidikan, Universitas Muhammadiyah Surakarta. 